\title{
Standard pH Values for the Potassium Hydrogen Phthalate Reference Buffer Solution from 0 to $60^{\circ} \mathrm{C}$
}

\author{
Hannah B. Hetzer and Richard A. Durst \\ Institute for Materials Research, National Bureau of Standards, Washington, D. C. 20234 \\ and
}

R. A. Robinson and Roger G. Bates

Department of Chemistry, University of Florida, Gainesville, Florida 32611

(December 27, 1976)

\begin{abstract}
The standard $\mathrm{pH}$ values of the solution of potassium hydrogen phthalate (molality $0.05 \mathrm{~mol} \mathrm{~kg}{ }^{-1}$ ) have been redetermined over the temperature range 0 to $60^{\circ} \mathrm{C}$, using SRM 185d. Extensive measurements were made of the emf of cells of the type
\end{abstract}

$\mathrm{Pd} ; \mathrm{H}_{2}(\mathrm{~g}, \mathrm{latm}) \mid \mathrm{KH}$ phthalate $(m=0.05), \mathrm{KCl}(m) \mid \mathrm{AgCl} ; \mathrm{Ag}$

where $m_{\mathrm{KCl}}$ was $0.015,0.01$, or $0.005 \mathrm{~mol} \mathrm{~kg}^{-1}$, from which values of the acidity function $\mathrm{p}\left(a_{\mathrm{H}} \gamma_{\mathrm{Cl}}\right)$ were derived. The $\mathrm{pH}$ convention defines $\gamma_{\mathrm{Cl}}$ in the range of ionic strengths 0 to $0.1 \mathrm{~mol} \mathrm{~kg}^{-1}$ and permits conventional values of $\mathrm{p} a_{\mathrm{H}}$ to be obtained. According to NBS procedures, $\mathrm{p} a_{\mathrm{H}}$ for selected reference solutions is identified with the standard $\mathrm{pH}(\mathrm{S})$ in the operational definition of $\mathrm{pH}$. The new values, given in terms of the thermodynamic temperature $(T)$ by

$$
\mathrm{pH}(\mathrm{S})=\frac{2073.44}{T}-13.3270+0.045199 T-3.4846 \times 10^{-5} T^{2}
$$

differ, on the average, by 0.003 unit from the results based on the 1944 data of Hamer and Acree.

Key words: Acidity; emf; $\mathrm{pH}$; phthalate buffer; potassium hydrogen phthalate; standard for $\mathrm{pH}$.

\section{Introduction}

The NBS standard $\mathrm{pH}$ scale is fixed by a series of primary standards $[1-3]^{1}$, the $\mathrm{pH}(\mathrm{S})$ values of which are based on precise emf measurements of cells without liquid junction of the type

$$
\text { Pt or } \mathrm{Pd} ; \mathrm{H}_{2}(\mathrm{~g}, \mathrm{l} \text { atm }) \mid \text { Buffer }+\mathrm{Cl}^{-} \mid \mathrm{AgCl} ; \mathrm{Ag}
$$

The $\mathrm{pH}$ is derived from the emf of cell $A$, together with a convention [4] relating the numerical value of the activity coefficient of chloride ion to the ionic strength $(I)$ and the temperature, where $0<I<0.1$. It has been shown [3] that, over the $\mathrm{pH}$ range 3.5 to 9.2 , this scale is internally consistent within 0.006 unit at $25{ }^{\circ} \mathrm{C}$ and within 0.013 unit at 10 and $40{ }^{\circ} \mathrm{C}$; that is to say, it is immaterial, within these limits, which of the standards is chosen for the calibration of $\mathrm{pH}$ measuring equipment in a given situation.

The solution of potassium hydrogen phthalate, molality $0.05 \mathrm{~mol} \mathrm{~kg}^{-1}$, is probably the most commonly used of the NBS primary standard reference solutions. It is likewise the

\footnotetext{
${ }^{1}$ Figures in brackets indicate the literature references at the end of this paper.
}

single primary standard of the British Standard Institution's $\mathrm{pH}$ scale [5]. This solution is easy to prepare from readily available certified material and is reasonably stable. Furthermore, its $\mathrm{pH}$ is not markedly sensitive to temperature changes and lies in the weakly acidic region where the practical measurement and control of acidity is often required.

The precise emf measurements, on which the NBS values for this important standard reference solution were originally based, were reported by Hamer, Pinching, and Acree between 1944 and 1946 [6-9]. The potassium hydrogen phthalate used in their work consisted of Standard Reference Materials 84a and 84b. These lots, certified for acidimetry, assayed very close to 100.00 percent. No extensive redetermination of $\mathrm{pH}(\mathrm{S})$ over the range 0 to $60{ }^{\circ} \mathrm{C}$ was undertaken preparatory to the certification of potassium hydrogen phthalate, SRM 185 , as a $\mathrm{pH}$ standard, but it was shown [9] that $0.05 \mathrm{~m}$ solutions prepared from lots $84 \mathrm{a}, 84 \mathrm{~b}, 84 \mathrm{c}$, and $185 \mathrm{had}$ the same $\mathrm{pH}$ value. The certification of three subsequent lots (SRM 185a, 185b, and 185c) was made by comparison, usually at $25^{\circ} \mathrm{C}$, of the emf of cell $A$ found for the 0.05 molal phthalate solution, with added $\mathrm{KCl}$, with corresponding data obtained in the earlier extensive investigation. The earlier values of $\mathrm{pH}(\mathrm{S})$ were then altered uniformly over the temperature range by an amount corresponding to the difference of 
emf found, at most a few thousandths of a $\mathrm{pH}$ unit. It is the purpose of this paper to report the results of a thorough study conducted prior to the certification of SRM 185d, a lot of which was shown by careful assay to have a purity of 99.99 percent and therefore presumably to be essentially identical with the material used in the earlier investigations of Hamer et al.

\section{Method}

The acidity function $\mathrm{p}\left(a_{\mathrm{H}} \gamma_{\mathrm{Cl}}\right)$ is readily calculated from the emf $(E)$ and standard emf $\left(E^{0}\right)$ of cell $A$ by the equation

$$
\mathrm{p}\left(a_{\mathrm{H}} \gamma_{\mathrm{Cl}}\right) \equiv-\log \left(m_{\mathrm{H}} \gamma_{\mathrm{H}} \gamma_{\mathrm{Cl}}\right)=\frac{\left(E-E^{0}\right) F}{R T \ln 10}+\log m_{\mathrm{Cl}}
$$

the molality of chloride ion $\left(m_{\mathrm{Cl}}\right)$ being known. As in the later work on the establishment of standard reference buffer solutions [10], three molalities of KCl, namely $0.015,0.01$, and $0.005 \mathrm{~mol} \mathrm{~kg}{ }^{-1}$, were used. The values of $\mathrm{p}\left(a_{\mathrm{H}} \gamma_{\mathrm{Cl}}\right)$ decreased linearly as $m_{\mathrm{KCl}}$ increased, and the intercepts $\mathrm{p}\left(a_{\mathrm{H}} \gamma_{\mathrm{Cl}}\right)^{0}$ at $m_{\mathrm{KCl}}=0$ were determined by linear regression analysis:

$$
\mathrm{p}\left(a_{\mathrm{H}} \gamma_{\mathrm{Cl}}\right)=\mathrm{p}\left(a_{\mathrm{H}} \gamma_{\mathrm{Cl}}\right)^{0}-b m_{\mathrm{KCl}}
$$

The final step in the assignment of standard values, $\mathrm{pH}(\mathrm{S})$, to the chloride-free phthalate buffer solution was the calculation of $\mathrm{p} a_{\mathrm{H}}$ from $\mathrm{p}\left(a_{\mathrm{H}} \gamma_{\mathrm{Cl}}\right)^{0}$ :

$$
\mathrm{pH}(\mathrm{S}) \equiv \mathrm{p} a_{\mathrm{H}}=\mathrm{p}\left(a_{\mathrm{H}} \gamma_{\mathrm{Cl}}\right)^{0}+\log \gamma_{\mathrm{Cl}}
$$

where $\gamma_{\mathrm{Cl}}$ is fixed by the $\mathrm{pH}$ convention proposed by Bates and Guggenheim [4]:

$$
\log \gamma_{\mathrm{Cl}}=\frac{-A I^{1 / 2}}{1+1.5 I^{1 / 2}}
$$

In eq (4), $A$ is the Debye-Hückel slope constant (molality scale) for the temperature in question [3]. This convention is intended to apply over the full temperature range but is restricted to ionic strengths $(I)$ no greater than $0.1 \mathrm{~mol} \mathrm{~kg}^{-1}$.

\section{Experimental Procedures}

In general, the experimental methods, including the preparation of the thermal-electrolytic silver-silver chloride electrodes [3] and the techniques of the emf measurements [11], were the same as those described in detail in other publications. Departures from these standard procedures are set forth below.

The platinum bases for the hydrogen electrodes must be coated with palladium black instead of platinum black, in order to minimize reduction of phthalate [12]. Preliminary measurements showed, however, that lightly coated electrodes were more stable than those with a heavier coat of palladium black. Accordingly, the platinum foils were electrolyzed at a current of about $30 \mathrm{~mA} \mathrm{~cm}^{-2}$ for 5 to 10 seconds in a 1 percent solution of palladium chloride acidified with $\mathrm{HCl}$ and containing $0.08 \mathrm{~g}$ of lead acetate trihydrate per 100 $\mathrm{ml}$ of plating solution. A strip of palladium metal served as anode.
Unfortunately, hydrogen electrodes prepared in this way are not as reproducible as are those coated with platinum black (when they can be used), and some instability at the higher temperatures gave testimony to a certain amount of reduction of phthalate. It was therefore necessary to adopt criteria for the rejection of a part of the cell data obtained in this extensive investigation. Each of the cells contained two electrodes of each kind, and the emf was measured both at the beginning and at the end of each temperature series. In general, the criteria for rejection were (a) differences greater than $0.1 \mathrm{mV}$ between pairs of electrodes in the same cell, and (b) differences greater than $0.3 \mathrm{mV}$ between the initial and final measurements at $25{ }^{\circ} \mathrm{C}$. Although some of the cells behaved acceptably over the entire 0 to $60{ }^{\circ} \mathrm{C}$ temperature range, for best results it was found necessary to use fresh electrodes and solutions for the range 40 to $60^{\circ} \mathrm{C}$. Thus, the results of only 3 cells out of 27 measured at $10{ }^{\circ} \mathrm{C}$ were rejected, whereas 25 of 44 were rejected at $50{ }^{\circ} \mathrm{C}$.

The standard emf $E^{0}$ of cell $A$ has been determined in two extensive series of measurements [13, 14]. Inasmuch as there is some evidence that $\mathrm{Ag} / \mathrm{AgCl}$ electrodes prepared in different laboratories by slightly differing procedures have slightly different potentials, it has been recommended [15] that $E^{0}$ be, in effect, redetermined under each set of experimental conditions by measurement of the emf of cell $A$ containing hydrochloric acid, molality $0.01 \mathrm{~mol} \mathrm{~kg}^{-1}$. Inasmuch as there is substantial agreement that the mean ionic activity coefficient (molality scale) of $\mathrm{HCl}$ has the values 0.904 at $25{ }^{\circ} \mathrm{C}$ and 0.908 at $0{ }^{\circ} \mathrm{C}$ in this solution [15], $E^{0}$ can be derived from these emf measurements.

Four investigators, namely V. E. Bower, R. Gary, H. B. Hetzer, and M. Paabo, prepared electrodes from materials used in their own studies, and the group prepared five cells from the same solution of $\mathrm{HCl}$, measuring the emf at three temperatures. The mean results for $E$ were $0.46102 \mathrm{~V}$ (standard deviation 0.00004 ) at $10{ }^{\circ} \mathrm{C}, 0.46425 \mathrm{~V}$ (s.d. 0.00010 ) at $25{ }^{\circ} \mathrm{C}$, and $0.46623 \mathrm{~V}$ (s.d. 0.00005 ) at $40{ }^{\circ} \mathrm{C}$, from which $E^{0}$ is $0.23153,0.22244$, and $0.21216 \mathrm{~V}$ at 10,25 , and $40^{\circ} \mathrm{C}$.

These results are higher than those found by Bates and Bower [14]; the differences are $0.11,0.09$, and $0.08 \mathrm{mV}$ at 10,25 , and $40{ }^{\circ} \mathrm{C}$, respectively. Hence, for the present study, $E^{0}$ at all temperatures from 0 to $60{ }^{\circ} \mathrm{C}$ was obtained by adding $0.1 \mathrm{mV}$ to the values given in the fifth column of table 1 , reference [14].

The potassium hydrogen phthalate, SRM 185d, had an assay value of 99.99 percent. It was shown to be equivalent to SRM 84a, one of the lots used by Hamer et al. [6-9], by measuring the emf of a cell of type $A$ containing $0.05 \mathrm{~m} \mathrm{KH}$ phthalate (SRM 84a) + 0.01m KCl at 25, 40, 45, 50, 55, and $60{ }^{\circ} \mathrm{C}$. The emf at these six temperatures differed on the average by only $0.07 \mathrm{mV}$ from the mean values found in the present investigation.

\section{Results}

The emf data from the cells meeting the criteria outlined above were corrected to $1 \mathrm{~atm}$ hydrogen pressure. They are numerous, and to conserve space the individual values (means of two pairs of electrodes in the same cell) have been averaged and the results summarized in table 1 , together with the number of cells and the mean deviation from the mean 
TABLE 1. Electromotive force of the cell: $\mathrm{Pd} ; \mathrm{H}_{2}(\mathrm{~g}, 1 \mathrm{~atm}) \mid \mathrm{KH}$ Phthalate $(\mathrm{m}=0.05), \mathrm{KCl}(\mathrm{m}) \mid \mathrm{AgCl} ; \mathrm{Ag}$ for $\mathrm{m}_{\mathrm{KCl}}=0.005,0.01$, and $0.015 \mathrm{~mol} \mathrm{~kg}{ }^{-1}$ from $O$ to $60^{\circ} \mathrm{C}$ (in volts)

\begin{tabular}{|c|c|c|c|c|c|c|c|c|c|}
\hline \multirow{2}{*}{$t /{ }^{\circ} \mathrm{C}$} & \multicolumn{3}{|c|}{$m_{\mathrm{KCl}}=0.005$} & \multicolumn{3}{|c|}{$m_{\mathrm{KCl}}=0.01$} & \multicolumn{3}{|c|}{$m_{\mathrm{KCl}}=0.015$} \\
\hline & No. of cells & $E /$ volts (mean) & Mean dev. ${ }^{a}$ & No. of cells & $E /$ volts (mean) & Mean dev. ${ }^{a}$ & No. of cells & $E /$ volts (mean) & Mean dev. ${ }^{a}$ \\
\hline 0 & 6 & 0.58311 & 0.03 & 8 & 0.56662 & 0.07 & 10 & 0.55695 & 0.09 \\
\hline 5 & 6 & 0.58666 & 0.04 & 8 & 0.56986 & 0.06 & 10 & 0.55996 & 0.07 \\
\hline 10 & 6 & 0.59015 & 0.03 & 8 & 0.57304 & 0.06 & 10 & 0.56297 & 0.07 \\
\hline 15 & 6 & 0.59366 & 0.05 & 8 & 0.57622 & 0.07 & 10 & 0.56601 & 0.08 \\
\hline 20 & 6 & 0.59713 & 0.06 & 8 & 0.57939 & 0.06 & 10 & 0.56900 & 0.08 \\
\hline 25 & 12 & 0.60060 & 0.06 & 12 & 0.58257 & 0.04 & 17 & 0.57199 & 0.09 \\
\hline 30 & 6 & 0.60402 & 0.09 & 8 & 0.58565 & 0.07 & 10 & 0.57493 & '0.10 \\
\hline 35 & 6 & 0.60742 & 0.13 & 8 & 0.58873 & 0.06 & 11 & 0.57786 & 0.12 \\
\hline 40 & 6 & 0.61104 & 0.15 & 6 & 0.59209 & 0.05 & 8 & 0.58090 & 0.08 \\
\hline 45 & 6 & 0.61444 & 0.12 & 6 & 0.59519 & 0.07 & 7 & 0.58385 & 0.13 \\
\hline 50 & 6 & 0.61787 & 0.09 & 6 & 0.59832 & 0.10 & 7 & 0.58680 & 0.13 \\
\hline 55 & 6 & 0.62131 & 0.09 & 6 & 0.60144 & 0.10 & 7 & 0.58969 & 0.15 \\
\hline 60 & 6 & 0.62474 & 0.08 & 6 & 0.60460 & 0.10 & 7 & 0.59266 & 0.12 \\
\hline
\end{tabular}

$a$ Mean deviation from the mean value of $E$, in $\mathrm{mV}$.

emf, in $\mathrm{mV}$. Only the initial results at $25{ }^{\circ} \mathrm{C}$ are given; the final results at this temperature were not used.

Values of the acidity function $\mathrm{p}\left(a_{\mathrm{H}} \gamma_{\mathrm{Cl}}\right)$ were calculated by eq (l) and the intercepts $\mathrm{p}\left(a_{\mathrm{H}} \gamma_{\mathrm{Cl}}\right)^{0}$ and slopes $b$ obtained by linear regression analysis; the relationship is shown in eq (2). This procedure was carried out in two ways: first, by use of the average $\mathrm{p}\left(a_{\mathrm{H}} \gamma_{\mathrm{Cl}}\right)$ values computed from the average emf's of table 1 , and second, by use of the entire population of $\mathrm{p}\left(a_{\mathrm{H}} \gamma_{\mathrm{Cl}}\right)$ values, that is, those derived from the emf of each individual cell. The intercepts obtained by the two procedures differed by considerably less than $0.001 \mathrm{pH}$ unit. The results collected in table 2 are nonetheless those obtained by treating each data point individually. The standard deviations of the intercepts and slopes are given, and the standard deviation for regression, expressed in $\mathrm{mV}$, appears in the last column.

TABLE 2. Linear regression analysis. Constants of equation (2)

\begin{tabular}{rcccccc}
\hline \hline$t /{ }^{\circ} \mathrm{C}$ & $n$ & $\mathrm{p}\left(a_{\mathrm{H}} \gamma_{\mathrm{Cl}}\right)^{\circ}$ & $b$ & $\begin{array}{c}\text { s.d. (inter- } \\
\text { cept) }\end{array}$ & s.d. (slope) & $\begin{array}{c}\text { s.d. (regres- } \\
\text { sion) }\end{array}$ \\
\hline 0 & 24 & 4.0944 & 0.612 & 0.0006 & 0.049 & 0.05 \\
5 & 24 & 4.0880 & 0.659 & 0.0008 & 0.070 & 0.08 \\
10 & 24 & 4.0857 & 0.669 & 0.0008 & 0.071 & 0.08 \\
15 & 24 & 4.0858 & 0.630 & 0.0009 & 0.082 & 0.09 \\
20 & 24 & 4.0881 & 0.627 & 0.0010 & 0.083 & 0.10 \\
25 & 41 & 4.0946 & 0.654 & 0.0006 & 0.054 & 0.08 \\
30 & 24 & 4.1005 & 0.641 & 0.0012 & 0.101 & 0.12 \\
35 & 25 & 4.1075 & 0.612 & 0.0013 & 0.115 & 0.13 \\
40 & 20 & 4.1223 & 0.788 & 0.0012 & 0.108 & 0.12 \\
45 & 19 & 4.1341 & 0.746 & 0.0014 & 0.128 & 0.15 \\
50 & 19 & 4.1482 & 0.749 & 0.0013 & 0.121 & 0.13 \\
55 & 19 & 4.1638 & 0.858 & 0.0016 & 0.144 & 0.17 \\
60 & 19 & 4.1803 & 0.818 & 0.0013 & 0.116 & 0.14 \\
\hline
\end{tabular}

${ }^{a}$ Expressed in $\mathrm{mV}$.

Application of the convention for $\gamma_{\mathrm{Cl}}$ set forth in eq (4) enables one to derive $\mathrm{pH}(\mathrm{S})$ from $\mathrm{p}\left(a_{\mathrm{H}} \gamma_{\mathrm{Cl}}\right)^{0}$ by eq (3). The ionic strength $(I)$ required for this purpose was calculated from the ionic compositions of potassium hydrogen phthalate solutions; these have been obtained by Hamer, Pinching, and Acree [9] from $K_{1}$ and $K_{2}$ for phthalic acid. The ionic strength is nearly constant over the temperature range 0 to $60{ }^{\circ} \mathrm{C}$,
TABLE 3. $p H(S)$ values for the potassium hydrogen phthalate solution, molality $=0.05 \mathrm{~mol} \mathrm{~kg}^{-1}$, from 0 to $60^{\circ} \mathrm{C}$

\begin{tabular}{|c|c|c|c|}
\hline \multirow{2}{*}{$t /{ }^{\circ} \mathrm{C}$} & \multirow{2}{*}{$\mathrm{NBS}^{a}$} & \multicolumn{2}{|c|}{ Present Work } \\
\hline & & exp. & calc. $^{b}$ \\
\hline 0 & 4.003 & $4.010_{1}$ & 4.0100 \\
\hline 5 & 3.999 & $4.003_{1}$ & 4.0035 \\
\hline 10 & 3.998 & $4.000_{2}$ & 4.0001 \\
\hline 15 & 3.999 & $3.999_{6}$ & 3.9994 \\
\hline 20 & 4.002 & $4.001_{2}$ & 4.0014 \\
\hline 25 & 4.008 & $4.007_{0}$ & 4.0058 \\
\hline 30 & 4.015 & $4.012_{1}$ & 4.0123 \\
\hline 35 & 4.024 & $4.018_{4}$ & 4.0208 \\
\hline 40 & 4.035 & $4.032_{4}$ & 4.0311 \\
\hline 45 & 4.047 & $4.043_{3}$ & 4.0431 \\
\hline 50 & 4.060 & $4.056_{6}$ & 4.0565 \\
\hline 55 & 4.075 & $4.071_{4}$ & 4.0712 \\
\hline 60 & 4.091 & $4.086_{9}$ & 4.0872 \\
\hline
\end{tabular}

${ }^{a}$ From the emf measurements of Hamer et al. [6] ; see reference [1].

${ }^{b}$ Calculated with use of equation (5).

varying only from 0.0532 to $0.0534 \mathrm{~mol} \mathrm{~kg}^{-1}$; $\log \gamma_{\mathrm{Cl}}$ decreases from -0.0843 at $0{ }^{\circ} \mathrm{C}$ to -0.0934 at $60{ }^{\circ} \mathrm{C}$. The values of $\mathrm{pH}(\mathrm{S})$ found in this way are listed in the third column of table 3 . With the aid of the OMNITAB computer program, they were fitted to the equation

$$
\begin{aligned}
\mathrm{pH}(\mathrm{S})=\frac{2073.44}{T}- & 13.3270 \\
+ & 0.045199 T-3.4846 \times 10^{-5} T^{2}
\end{aligned}
$$

where $T$ is the thermodynamic temperature. Calculated values of $\mathrm{pH}(\mathrm{S})$ are given in the last column of the table. From a comparison of the experimental $\mathrm{pH}(\mathrm{S})$ with that calculated by eq (5), there is a standard deviation for regression of 0.0010 unit.

\section{Discussion}

The values of $\mathrm{pH}(\mathrm{S})$ labeled "NBS" in table 3 were derived [1] from the emf measurements of Hamer and Acree [6]. The 
original emf data, reported in international volts, were corrected to the absolute scale and $\mathrm{p}\left(a_{\mathrm{H}} \gamma_{\mathrm{Cl}}\right)$ obtained with the aid of $E^{0}$ from the study of Bates and Bower [14]. The $\mathrm{pH}(\mathrm{S})$ values resulting from the application of the $\gamma_{\mathrm{Cl}}$ convention to $\mathrm{p}\left(a_{\mathrm{H}} \gamma_{\mathrm{Cl}}\right)^{0}$ were fitted to a four-constant equation of the same form as eq (5). The mean difference between experimental and calculated $\mathrm{pH}(\mathrm{S})$ at the 13 temperatures was $0.002_{1}$. The smoothed values from this equation are listed in the second column of table 3 . In general, the present results for temperatures below $20{ }^{\circ} \mathrm{C}$ are slightly higher than those derived from the earlier data, and they are lower when the temperature lies between 20 and $60{ }^{\circ} \mathrm{C}$. Nevertheless, the mean difference for all 13 temperatures is only $0.003_{3}$ unit.

In 1946, Hamer, Pinching, and Acree [9] calculated the $\mathrm{p} a_{\mathrm{H}}$ values of solutions of potassium hydrogen phthalate at eight different molalities, 0.001 to $0.2 \mathrm{~mol} \mathrm{~kg}^{-1}$, from $K_{1}$ and $K_{2}$ for phthalic acid and ionic activity coefficients estimated in a manner different from the convention of eq (4). At a molality of $0.05 \mathrm{~mol} \mathrm{~kg} \mathrm{~g}^{-1}$, the values obtained in this way are in somewhat better agreement with those of the present study than are the values labeled "NBS" in table 3. The mean difference is $0.002_{2}$ at the 13 temperatures; if 55 and $60{ }^{\circ} \mathrm{C}$ (where the differences are 0.006 and $0.010 \mathrm{pH}$ unit, respectively) are omitted, the mean difference is only 0.001 unit.

The largest differences between the values in the second and third columns of table 3 occur at 0 and $35^{\circ} \mathrm{C}$. In this connection, it is noteworthy that the experimental value from the earlier work is 4.006 at $0{ }^{\circ} \mathrm{C}$; here smoothing has accentuated the discrepancy. Furthermore, the values of the present study for the range 40 to $60{ }^{\circ} \mathrm{C}$ are based largely on a different set of cells and solutions from those for $35^{\circ} \mathrm{C}$ and below. The greatest disparity between experimental and calculated $\mathrm{pH}(\mathrm{S})$, namely 0.0024 unit, occurs at $35{ }^{\circ} \mathrm{C}$, and it seems likely that the experimental result at this temperature is slightly low. No explanation for this inconsistency can be found, yet its existence appears to be sufficient justification to regard the smoothed values of the last column as the more reliable and self-consistent set.

\section{References}

[1] Bates, R. G., J. Res. Nat. Bur. Stand. (U.S.), 66A (Phys. and Chem.), No. 2, 179-184 (Mar.-Apr. 1962).

[2] Durst, R. A., Standard reference materials: standardization of $\mathrm{pH}$ measurements, Nat. Bur. Stand. (U.S.), Spec. Publ. 260-53, 48 pages (Dec. 1975).

[3] Bates, R. G., Determination of $\mathrm{pH}$, 2nd ed., ch. 4 and 10 and appendix (John Wiley \& Sons, New York, N. Y., 1973).

[4] Bates, R. G., and Guggenheim, E. A., Pure Appl. Chem. 1, 163 (1960).

[5] Specification for the $\mathrm{pH}$ scale, British Standard 1647 (British Standards Institution, London, 1961).

[6] Hamer, W. J., and Acree, S. F., J. Res. NBS 32, 215 (1944) RP1586.

[7] Hamer, W. J., and Acree, S. F., J. Res. NBS 35, 381 (1945) RP1678.

[8] Hamer, W. J., Pinching, G. D., and Acree, S. F., J. Res. NBS 35, 539 (1945) RP1687.

[9] Hamer, W. J., Pinching, G. D., and Acree, S. F., J. Res. NBS 36, 47 (1946) RP1690.

[10] Staples, B. R., and Bates, R. G., J. Res. Nat. Bur. Stand. (U.S.), 73A (Phys. and Chem.), No. 1, 37-41 (Jan.-Feb. 1969).

[11] Hetzer, H. B., Robinson, R. A., and Bates, R. G., J. Phys. Chem. 68, 1929 (1964).

[12] Hamer, W. J., and Acree, S. F., J. Res. NBS 33, 87 (1944) RP1598.

[13] Harned, H. S., and Ehlers, R. W., J. Am. Chem. Soc. 54, 1350 (1932); 55, 2179 (1933).

[14] Bates, R. G., and Bower, V. E., J. Res. NBS 53, 283 (1954) RP2546.

[15] Bates, R. G., Guggenheim, E. A., Harned, H. S., Ives, D. J. G., Janz, G. J., Monk, C. B., Prue, J. E., Robinson, R. A., Stokes, R. H., and Wynne-Jones, W. F. K., J. Chem. Phys. 25, 361 (1956); 26, 222 (1957).

(Paper 81A1-921) 